\title{
Relationship between plasma lipid profile and the severity of diabetic retinopathy in type 2 diabetes patients
}

\author{
Rianita $^{1}$, Saptawati Bardosono ${ }^{1}$, Andi Arus Victor ${ }^{2}$
}

\begin{abstract}
Abstrak
Penelitian ini bertujuan untuk mengetahui hubungan antara profil lipid darah dengan derajat retinopati diabetik penderita DM tipe-2. Penelitian potong-lintang pada 52 pasien retinopati diabetika dilaksanakan di Poliklinik Mata, Rumah Sakit Cipto Mangunkusumo, Jakarta. Data yang dikumpulkan meliputi data demografi, gaya hidup, lama menderita DM, pemeriksaan fisik dan antropometrik, asupan lemak, asam lemak dan kolesterol data kadar gula darah puasa, A1C, kolesterol total, kolesterol-LDL, kolesterol-HDL and trigliserida, dan pemeriksaan fundus. Analisis statistik yang digunakan adalah uji chi-square untuk mengetahui hubungan antara profil lipid darah dengan derajat retinopati diabetik. Subyek terdiri dari 20 orang laki-laki dan 32 orang perempuan dengan rerata usia 53,8 \pm 5,2 tahun. Sebanyak 53,8\% telah didiagnosis DM selama $>10$ tahun, dengan rerata IMT adalah $24,1 \pm 3,3 \mathrm{~kg} / \mathrm{m}^{2}$ dan $38,5 \%$ diklasifikasikan sebagai obes I dan II. Rerata kadar gula darah puasa 157,5 \pm 71,8 mg/dL, dan A1C 9,1 $\pm 2,4 \%$. Sebanyak 40,4\% subyek mempunyai kadar kolesterol total darah tinggi, 34,6\% kadar kolesterol-LDL darah sangat tinggi, dan 65,4\% dengan kolesterol-HDL dan trigliserida darah normal. Derajat keparahan retinopati diabetika ditunjukkan dengan adanya $61,6 \%$ subyek dengan retinopati diabetika nonproliferasi berat (NPDR) and retinopati diabetika proliferasi (PDR). Kesimpulannya, belum dapat dibuktikan adanya hubungan yang bermakna antara profil lipid dengan derajat retinopati diabetika. (Med J Indones 2008; 17: 221-5)
\end{abstract}

\begin{abstract}
This study aimed to determine the relationship between plasma lipid profile and the severity of diabetic retinopathy in type 2 diabetes patients. A cross sectional study was done in Ophthalmologic Clinic, Cipto Mangunkusumo General Hospital, Jakarta for 52 diabetic retinopathy (DR) patients. Data collected were demographic, life style, duration of diabetes, physical and antropometric examinations, fat, fatty acid and cholesterol intake, fasting plasma glucose, A1C, total-, LDL-, HDL-cholesterol and triglyceride level, and fundus examination. Statistical analysis was done using chi-square test to see the associations between plasma lipid profile and DR in type 2 diabetes patients. Subjects comprised of 20 males and 32 females diabetes patients with mean age of $53.8 \pm 5.2$ years. As much as $53.8 \%$ had been diagnosed as DM for $>10$ years. The mean value of BMI was $24.1 \pm 3.3 \mathrm{~kg} / \mathrm{m}^{2}$ and $38.5 \%$ were classified as obese I and II. The mean value of fasting plasma glucose was $157.5 \pm 71.8 \mathrm{mg} / \mathrm{dL}$, and AlC was $9.1 \pm 2.4 \%$. For lipid profile, $40.4 \%$ had high total cholesterol level (>240 mg/dL), 34.6\% had high and very high LDL-cholesterol level ( $\geq 160 \mathrm{mg} / \mathrm{dL})$, and $65.4 \%$ had normal HDLcholesterol $(40-60 \mathrm{mg} / \mathrm{dL})$ and triglyceride level $(<150 \mathrm{mg} / \mathrm{dL})$. For the severity of retinopathy, 61.6\% had severe non-proliferative diabetic retinopahy $(N P D R)$ and proliferative diabetic retinopahy (PDR). In conclusion, there were no significant associations between plasma lipid profile and the severity of diabetic retinopathy. (Med J Indones 2008; 17: 221-5)
\end{abstract}

Keywords: Fat intake, lipid profile, diabetic retinopathy

Diabetes mellitus is continuing to become a health problem because the prevalence of DM increases dramatically over the past two decades. ${ }^{1}$ Prevalence of diabetic retinopathy (DR), the ophthalmologic com-

\footnotetext{
${ }^{1}$ Department of Nutrition, Faculty of Medicine University of Indonesia, Jakarta, Indonesia

2 Department of Ophthalmology, Faculty of Medicine University of Indonesia/Dr. Cipto Mangunkusumo Hospital, Jakarta, Indonesia
}

plication of DM, in Indonesia is $27.1 \% .^{2}$ Strategies to prevent the development and progression of DR is very crucial regarding its blindness end result. Risk factors of DR among others are hyperglycemia, hypertension, pregnancy, obesity and dyslipidemia. ${ }^{3-6}$ Dyslipidemia associated with DM are hyper triglyceride and decrease HDL-cholesterol concentrations. ${ }^{1,7}$

Chen et al found that dyslipidemia, not hyperglycemia, that induces inflammatory adhesion molecules expression 
in microvascular human retinal vascular endothelial cells. ${ }^{8}$ High lipid levels are known to cause endothelial dysfunction via a local inflammatory response resulting in the release of cytokines and growth factors, activation of oxygen-sensitive biological changes in vessel walls, increased low-density lipoprotein (LDL) oxidation, and quenching of nitric oxide. Endothelial dysfunction in diabetic vasculature results in blood-retinal barrier breakdown that will lead to DR. Elevated level of LDL and triglycerides in DM have been linked with higher levels of advanced glycation end products, which play an important role in the pathogenesis of diabetic complications. ${ }^{6,9,10}$

Previous studies found that high dietary fat intake among DM patients at Cipto Mangunkusumo General Hospital (27.3\%-33\% total energy intake). ${ }^{11,12}$ High intake of dietary fat will influence plasma lipid profile and worsen the existing abnormal metabolism. This research was aimed to investigate the associations between dietary fat intake, plasma lipid profile and DR in type 2 diabetes patients.

\section{METHODS}

Fifty two diabetic retinopathy patients were consecutively recruited from Ophthalmology Clinic at Dr Cipto Mangunkusumo General Hospital, Jakarta. The inclusion criteria was age under 60 years while the exclusion criteria were pregnant, lactating woman and/or taking antihyperlipidemic agent. All participants were given written informed consent. The study protocol was approved by The Medical Research Ethics Committee of The Faculty of Medicine University of Indonesia.

This was a cross sectional study to collect data by interview, medical records, physical and laboratory examination. Data collected were demographic characteristics, life style, duration of diabetes, physical and antropometri examinations, fat, fatty acid and cholesterol intake by FFQ semiquantitative method, laboratory (fasting plasma glucose, A1C, totalcholesterol, LDL-, HDL-cholesterol and triglyceride level), and fundus examination.

Body weight was measured using a digital Seca scale with accuracy to the nearest $0.1 \mathrm{~kg}$. Body height was measured using a microtoise with accuracy to the nearest $0.1 \mathrm{~cm}$. Both measures were used to classify nutritional status of the subjects based on body mass index (BMI). Nutrients intake was analyzed using data provided from the semi-quantitavie food-frquency questionnaires. Blood samples were analyzed for glycaemic control (blood glucose and A1C) and classified using local reference (PERKENI, 2006) and lipid profile was analyzed by using high performance liquid chromatography and classified using NCEP-ATP III 2001 reference. Classification of retinopathy was based Victor et al (1999) reference.

The data were analyzed using SPSS version 11.5. All group data were presented as frequency distribution (proportion) and the average values was presented as means \pm SD for the normal distribution data and as median (minimum-maximum) for the non normal distribution data. Data were analysed statistically using chi-square or fischer exact test to see the associations between plasma lipid profile and DR in type 2 diabetes patients. The minimal level of significance was set at $\mathrm{p}<0.05$.

\section{RESULTS}

Subjects comprised of $20(38.5 \%)$ males and $32(61.5 \%)$ females, with mean age of $53.8 \pm 5.2$ years. Majority of the subjects $(80 \%)$ had low and moderate education level, $94.2 \%$ were above the poverty line, $53.8 \%$ had been diagnosed DM for $>10$ years, $88.5 \%$ were nonsmokers and $57.7 \%$ had low physical activity index. The mean value of BMI was $24.1 \pm 3.3 \mathrm{~kg} / \mathrm{m}^{2}$, which were within the risk range for obeisty and $38.5 \%$ of the subjects were classified as obese I and II (Table 1).

The mean value of systolic blood pressure was 137.4 $\pm 21.8 \mathrm{mmHg}$, diastolic blood pressure $81.5 \pm 21.8$ $\mathrm{mmHg}$, fasting plasma glucose $157.5 \pm 71.8 \mathrm{mg}$ / $\mathrm{dL}, \mathrm{A} 1 \mathrm{C} 9.1 \pm 2.4 \%$. As much as $40.4 \%$ had high total cholesterol level, $34.6 \%$ had high and very high LDL-cholesterol level, and $65.4 \%$ had normal HDLcholesterol and triglyceride level (Table 2). The median of dietary fat intake was 39.5 (8-146) g/day and 78.8\% had high fat intake, $94,2 \%$ had high SAFA intake, all of the subjects had enough PUFA and MUFA intake, and $94,2 \%$ had enough cholesterol intake (Table 3 ).

There were no significant association between plasma lipid profile and the severity of DR (Table 4). 
Table 1. Characteristics of the subjects $(n=52)$

\begin{tabular}{lcc}
\hline Characteristics & Frequency & $\begin{array}{c}\text { Percentage } \\
(\%)\end{array}$ \\
\hline Sex: Male & 20 & 38.5 \\
Female & 32 & 61.5 \\
Educational level: Low & 22 & 42.3 \\
Moderate & 20 & 38.5 \\
High & 10 & 19.2 \\
Incomes: Above poverty level & 3 & 5.8 \\
Below poverty level & 49 & 94.2 \\
Duration DM: $\leq 10$ years & 24 & 46.2 \\
>10 years & 28 & 53.8 \\
Smoking: Non smokers & 46 & 88.5 \\
Light smokers & 2 & 3.8 \\
Moderate smokers & 3 & 5.8 \\
Heavy smokers & 1 & 1.9 \\
Physical activity: Low & 30 & 57.7 \\
$\quad$ Moderate & 13 & 25.0 \\
High & 9 & 17.3 \\
BMI: Underweight & 2 & 3.8 \\
Normal & 18 & 34.6 \\
Overweight & 12 & 23.1 \\
Risk & 3 & 32.7 \\
Obes I & & 5.8 \\
Obes II & & \\
\hline
\end{tabular}

BMI, body mass index

Table 2. Physical examination and laboratory data of the subjects $(n=52)$

\begin{tabular}{lccc}
\hline Variables & Frequency & $\begin{array}{c}\text { Percentage } \\
(\%)\end{array}$ \\
\hline Systolic BP: Normal & 7 & 13.5 \\
Prehypertension & 20 & 38.5 \\
Hypertension I & 15 & 28.8 \\
Hypertension II & 10 & 19.2 \\
Diastolic BP: Normal & & \\
Prehypertension & 14 & 38.5 \\
& Hypertension I & 15 & 26.9 \\
Hypertension II & 3 & 28.8 \\
Fasting glucose level: Good & 15 & 5.8 \\
& Moderate & 5 & 28.8 \\
& Bad & 32 & 9.6 \\
A1C: Good & & & 61.5 \\
Moderate & 10 & 15.4 \\
Bad & & 34 & 65.4 \\
\hline
\end{tabular}

Table 2. Physical examination and laboratory data of the subjects $(n=52)$

\begin{tabular}{|c|c|c|}
\hline Variables & Frequency & $\begin{array}{c}\text { Percentage } \\
(\%)\end{array}$ \\
\hline Total cholesterol: Desirable & 17 & 32.7 \\
\hline Borderline high & 14 & 26.9 \\
\hline High & 21 & 40.4 \\
\hline LDL cholesterol: Optimal & 7 & 13.5 \\
\hline Near optimal & 8 & 15.4 \\
\hline Borderline high & 19 & 36.5 \\
\hline High & 9 & 17.3 \\
\hline Very high & 9 & 17.3 \\
\hline HDL cholesterol: High & 34 & 65.4 \\
\hline Low & 18 & 34.6 \\
\hline Triglyceride: Desirable & 34 & 65.4 \\
\hline Borderline high & 6 & 11.5 \\
\hline High & 11 & 21.2 \\
\hline Very high & 1 & 1,9 \\
\hline
\end{tabular}

BP, blood pressure; A1C, glycosilated haemoglobin; LDL, lowdensity lipoprotein; HDL, high-density lipoprotein

Table 3. Fat, fatty acid and cholesterol intake of the subjects $(n=52)$

\begin{tabular}{lcc}
\hline Intake & Frequency & Percentage (\%) \\
\hline Fat: Low & 5 & 9.6 \\
Moderate & 6 & 11.5 \\
High & 41 & 78.8 \\
& & 5.8 \\
SAFA: Low & 3 & 94.2 \\
$\quad$ Moderate & 49 & 100 \\
PUFA: Moderate & 52 & 100 \\
MUFA: Moderate & 52 & 94.2 \\
Cholesterol: Moderate & 49 & 5.8 \\
$\quad$ High & 3 & \\
\hline
\end{tabular}

SAFA, saturated fatty acid; PUFA, poly-unsaturated fatty acid; MUFA, mono-unsaturated fatty acid 
Table 4. Associations of lipid profile and diabetic retinopathy $(n=52)$

\begin{tabular}{|c|c|c|c|c|c|c|c|}
\hline \multirow{2}{*}{ Lipid profile } & \multirow{2}{*}{ Category } & & \multicolumn{4}{|c|}{ Diabetic retinopathy, $n(\%)$} & \multirow{2}{*}{$p$} \\
\hline & & & $\begin{array}{c}\text { Mild } \\
\text { NPDR }\end{array}$ & $\begin{array}{l}\text { Moderate } \\
\text { NPDR }\end{array}$ & $\begin{array}{l}\text { Severe } \\
\text { NPDR }\end{array}$ & PDR & \\
\hline \multirow[t]{3}{*}{ Total cholesterol } & Desirable & Borderline & $4(44.4)$ & $2(18.2)$ & $4(33.3)$ & $7(35.0)$ & 0.858 \\
\hline & high & & $3(33.3)$ & $3(27.3)$ & $3(25.0)$ & $5(25.0)$ & \\
\hline & High & & $2(22.2)$ & $6(54.4)$ & $5(41.7)$ & $8(40.0)$ & \\
\hline \multirow[t]{6}{*}{ LDL cholesterol } & Optimal & & $6(66.7)$ & $7(63.6)$ & $7(58.3)$ & $14(70.0)$ & 0.569 \\
\hline & Near optimal & & 0 & $3(27.3)$ & $2(16.7)$ & $1(5.0)$ & \\
\hline & Borderline high & & $3(33,3)$ & $1(9.1)$ & $3(25.0)$ & $4(20.0)$ & \\
\hline & High & & 0 & 0 & 0 & $1(5.0)$ & \\
\hline & Very high & & & & & & \\
\hline & & & $1(11.1)$ & $1(9.1)$ & 0 & $5(25.0)$ & 0.190 \\
\hline \multirow[t]{3}{*}{ HDL cholesterol } & High & & $1(11.1)$ & 0 & $4(33.3)$ & $3(15.0)$ & \\
\hline & Low & & $6(66.7)$ & $5(45.5)$ & $2(16.7)$ & $6(30.0)$ & \\
\hline & & & $1(11.1)$ & $3(27.3)$ & $3(25.0)$ & $2(10.0)$ & \\
\hline \multirow[t]{4}{*}{ Triglyceride } & Desirable & & 0 & $2(18.2)$ & $3(25.0)$ & $4(20.0)$ & \\
\hline & Borderline high & & & & & & \\
\hline & High & & $2(22.2)$ & $2(18.2)$ & $5(41.7)$ & $9(45.0)$ & 0.371 \\
\hline & Very high & & $7(77.8)$ & $9(81.8)$ & $7(58.3)$ & $11(55.0)$ & \\
\hline
\end{tabular}

LDL, low-density lipoprotein; HDL, high-density lipoprotein; NPDR, non-proliferative diabetic retinopathy; PDR, proliferative diabetic retinopathy

\section{DISCUSSION}

The present study showed that most of the subjects were diagnosed as having severe DR (severe NPDR and PDR). As much as $25 \%$ of the male subjects were diagnosed as having PDR and most of the female subjects had moderate NPDR. The Wisconsin Epidemiologic Study of Diabetic Retinopathy (WESDR) showed a similar trend where male had more PDR than female. ${ }^{13}$ The mean age of the subjects was $53.8 \pm 5.2$ years. Epidemiologic studies showed an increased prevalence of DR with increasing age in the younger-onset of DM. Increases in growth hormone, insulin-like growth factor 1, sex hormone, poor glycemic control have been hypothesized to explain the higher risk of DR in the younger-onset of DM. ${ }^{14}$

This study didn't find any trend on the increased of PDR subjects when total cholesterol level increased. This condition might be related to the fact that most of the PDR subjcts had normal plasma triglyceride level and borderline to a very high plasma LDLcholesterol level. There were PDR subjects with low
HDL-cholesterol level as much as PDR subjects with high HDL-cholesterol level.

There were no significant associations between plasma lipid profile and DR by bivariate statistical analysis. This could be explained by the fact that most of the subjects had normal plasma triglyceride and total cholesterol level. Abnormalities in lipid profile that could be associated with DR are high plasma triglyceride and total cholesterol. Beside that, most of the subjects had poor glycemic control in which glycemic control is known as the most important risk factors for DR. This result was similar to the study by Lyons et al that showed no significant association between plasma triglyceride, LDL- and HDLcholesterol level with DR. Lyons et al found that DR had a significant positive association with LDL smalldense and significant negative association with HDL. ${ }^{16}$ Previous studies showed a significant association between plasma lipid profile. ${ }^{5,9,17}$ Haddad and Saad found that plasma total cholesterol and triglyceride were risk factors for DR. ${ }^{18}$ 
It is concluded that there was no association between plasma lipid profile and the severity of DR.

\section{REFERENCES}

1. Powers AC. Diabetes Mellitus. In: Kasper DL, Braunwald E, Fauci AS, Hauser SL, Longo DL, Jameson JL, editors. Harrison's Principles of Internal Medicine. $16^{\text {th }}$ ed. New York: McGraw-Hill; 2005.p.2152-93

2. Suyono S. Kecenderungan peningkatan jumlah penyandang diabetes. In: Soegondo S, Soewondo P, Subekti I, editors. Penatalaksanaan Diabetes Melitus Terpadu. Jakarta: Balai Penerbit FKUI; 2005.p.1-5

3. Kanski JJ. Clinical Ophthalmology. $4^{\text {th }}$ ed. Oxford: Butterworth Heinemann; 2000. p.465-79

4. Rand LI. Diabetes and the eye. In: Becker KL, editor. Principles and Practice of Endocrinology and Metabolism. $3^{\text {th }}$ ed. Philadelphia: Lippincott Williams and Wilkins; 2001. p.1418-23.

5. Van Leiden H, Dekker JM, Moll AC, Nijpels G, Heine RJ, Bouter LM, Stehouwer CDA, Polak BCP. Blood pressure, lipids and obesity are associated with retinopathy. Diabetes Care. 2002; 25: 1320-25

6. Ciulla TA, Amador AG, Zinman B. Diabetic retinopathy and diabetic macular edema. Diabetes Care 2003; 26: 2653-63

7. Krauss RM, Siri PW. Dyslipidemia in type 2 diabetes. Med Clin N Am. 2004; 88: 897-909

8. Chen W, Jump DB, Grant MB, Esselman WJ, Busik JV. Dyslipidemia, not hyperglycemia, induces inflammatory adhesion molecules in human retinal vascular endothelial cells. Invst Ophthalmol. Vis Sci. 2003; 44: 5016-22

9. Miljanovic B, Glynn RJ, Nathan DM, Manson JE, Schaumberg DA. A prospective study of serum lipids and risk of diabetic macular edema in type 1 diabetes. Diabetes. 2004; 53: 2883-92
10. Leiter LA. The prevention of diabetic microvascular complications of diabetes: is there a role for lipid lowering?. Diabetes research and clinical practice 2005; 68S2: S3S14

11. Fitriyani S. Korelasi antara kadar vitamin E dengan malondilaldehida dan c-reactive protein plasma penderita diabetes melitus tipe 2. Tesis Magister Sains. Jakarta: Ilmu Gizi Klinik FKUI; 2006

12. Ambarwati FD. Indeks glikemik dan beban glikemik kue tradisional di pasaran dan kue sejenis buatan sendiri yang ditambah serat makanan pada kelompok DM tipe 2 dan non DM. Tesis Magister Sains. Jakarta: Ilmu Gizi Klinik FKUI; 2006

13. Klein R, Klein BE. The epidemiology of diabetic retinopathy. In: Ryan SJ, Schachat AP, editors. Retina. $4^{\text {th }}$ ed. Philadelphia: Elsevier Mosby; 2006. p.1503-21

14. Klein R. () Retinopathy and other ocular complications in diabetes. In: Porte D, Sherwin RS, Baron A, editors. Ellenberg \& Rifkin's Diabetes mellitus. $6^{\text {th }}$ ed. New York: McGraw-Hill; 2003.p.663-94

15. Durrington PN. () Hyperlipidaemia diagnosis and management. $1^{\text {st }}$ ed. London: Wright; 1989.p.166-94

16. Lyons TJ, Jenkins AJ, Zheng D, Lackland DT, McGee D, Garvey WT, Klein RL, The DCCT/EDIC Research Group. Diabetic retinopathy and serum lipoprotein subclasses in the DCCT/EDIC cohort. Invest. Ophthalmol. Vis Sci. 2004; 45: $910-18$

17. Klein BEK, Moss SE, Klein R, Surawicz TS. The Wisconsin epidemiologic study of diabetic retinopathy. XIII. Relationship of serum cholesterol to retinopathy and hard exudate. Ophthalmology. 1991; 98: 1261-65

18. Haddad OAW, Saad MK. Prevalence and risk factors for diabetic retinopathy among Omani diabetics. $\mathrm{Br} \mathrm{J}$ Ophthalmol. 1998; 82: 901-06 